University of Nebraska - Lincoln

DigitalCommons@University of Nebraska - Lincoln Kazakh Steppes

Kirsten M. de Beurs

University of Nebraska - Lincoln

Geoffrey M. Henebry

University of Nebraska - Lincoln, geoffrey.henebry@sdstate.edu

Anatoly A. Gitelson

University of Nebraska - Lincoln, agitelson2@unl.edu

Follow this and additional works at: https://digitalcommons.unl.edu/natrespapers

Part of the Natural Resources and Conservation Commons

de Beurs, Kirsten M.; Henebry, Geoffrey M.; and Gitelson, Anatoly A., "Regional MODIS Analysis of Abandoned Agricultural Lands in the Kazakh Steppes" (2004). Papers in Natural Resources. 241. https://digitalcommons.unl.edu/natrespapers/241

This Article is brought to you for free and open access by the Natural Resources, School of at DigitalCommons@University of Nebraska - Lincoln. It has been accepted for inclusion in Papers in Natural Resources by an authorized administrator of DigitalCommons@University of Nebraska - Lincoln. 


\section{Regional MODIS analysis of abandoned agricultural lands in the Kazakh steppes}

\author{
Kirsten M. de Beurs, M.Sc. \\ Geoffrey M. Henebry, Ph.D. \\ Anatoly A. Gitelson, Ph.D. \\ School of Natural Resources \\ 102 E. Nebraska Hall \\ University of Nebraska - Lincoln \\ kdebeurs@,calmit.unl.edu \\ ghenebry@calmit.unl.edu \\ gitelson@calmit.unl.edu
}

\begin{abstract}
The institutional consequences of the Soviet Union's collapse in 1991 have been greatly underestimated as a significant forcing on the boundary layer through changes in land surface phenology. Upon independence, Kazakhstan lost the centralized agricultural planning, crop subsidy system, and access to international markets that the Soviet Union had been providing. These institutional changes led to substantial decreases in livestock populations, especially sheep, and in arable land area cultivated, especially rain-fed spring wheat in northern Kazakhstan. As a result the fallow fields reverted to weedy species and idle pastures produced denser grass cover.
\end{abstract}

In this case study we used MODIS imagery from three consecutive growing seasons (2001-2003) to study the processes that occur after arable land has been abandoned, a process that is often underestimated in carbon cycle modeling, but which is especially important in central and northern Eurasia.

We selected two study regions in northern Kazakhstan: one in the Kazakh forest steppe ecoregion and another in the Kazakh steppe ecoregion. Within each region we visually determined a spring wheat area, and an area with other land cover. We then constructed land surface phenology models based on MODIS imagery from March 2001 through October 2003 and accumulated growing degree-days (AGDD) calculated from the NCEP/NCAR Reanalysis data. Comparisons among these phenology models provide insight into the land cover change trajectories that have occurred since large areas of arable land have gone fallow. Furthermore, we determine the change in parameters based on different land cover percentages. We have shown that abandoned arable lands green up before croplands that are plowed for planting in the last week of May. This may explain, in part, the "greening trend" that has been observed over northern Eurasia by other investigations [1]-[4].

Keywords-Eurasia; MODIS; Land Surface Phenology; Institutional Change

This work was supported by the NASA Land Cover Land Use Change (LCLUC) program.

\section{INTRODUCTION}

Kazakhstan became independent in 1991 after the collapse of the Soviet Union. As a result of this institutional change, the agricultural sector contracted leading to large decreases in spring wheat $(-33 \%)$ and livestock $(-70 \%)[5]$. Our aim has been to understand whether the institutional change had a significant influence on the land surface phenology as observed by synoptic sensors. Using Pathfinder AVHRR Land (PAL) data we have previously compared the land surface phenology before and after institutional change in Kazakhstan [6]. We estimated land surface phenology models based on accumulated growing degree-days and NDVI data from 1985 to 1988 and from 1995 to 1999 and compared the coefficients of the model parameters. We found higher intercepts and earlier peaks for the second time period. We concluded that there was a statistically significant change in land surface phenology following institutional change. Spring wheat gets planted in the end of May, much later than the beginning of the growing season for native vegetation. We concluded that the observed increase in greenness resulted from the introduction of another land cover with an earlier phenology. Agricultural deintensification across the region could have this kind of significant impact on land surface phenology.

In contrast to our previous studies with the $8 \mathrm{~km}$ NDVI data from PAL, we focus here on two of the same regions we considered earlier using much finer spatial resolution MODIS NDVI data from the Terra platform. We determine differences in land surface phenology between regions with and without crop production. As MODIS data were unavailable during earlier time periods, we are unable to estimate the exact amount of land that fell out of production. We compare the result with the Eurasia Land Cover Characteristics database $(1 \mathrm{~km})$ [7]. Finally, we demonstrate how the average NDVI from this region could be influenced by a change in the proportion of land cover types with differing phenologies.

\section{METHODS AND DATA}

\section{A. MODIS}

We acquired 45 ten-day periods of MODIS data ranging from the last dekad in April till the last dekad in September, for 2001 through 2003 from the Space Research Institute in Kazakhstan. The third dekad of June 2001, the third dekad of July 2001 and the second dekad in September 2002 are missing from the data. The MODIS data have a spatial resolution of 250 meters and we use maximum value NDVI composites. 

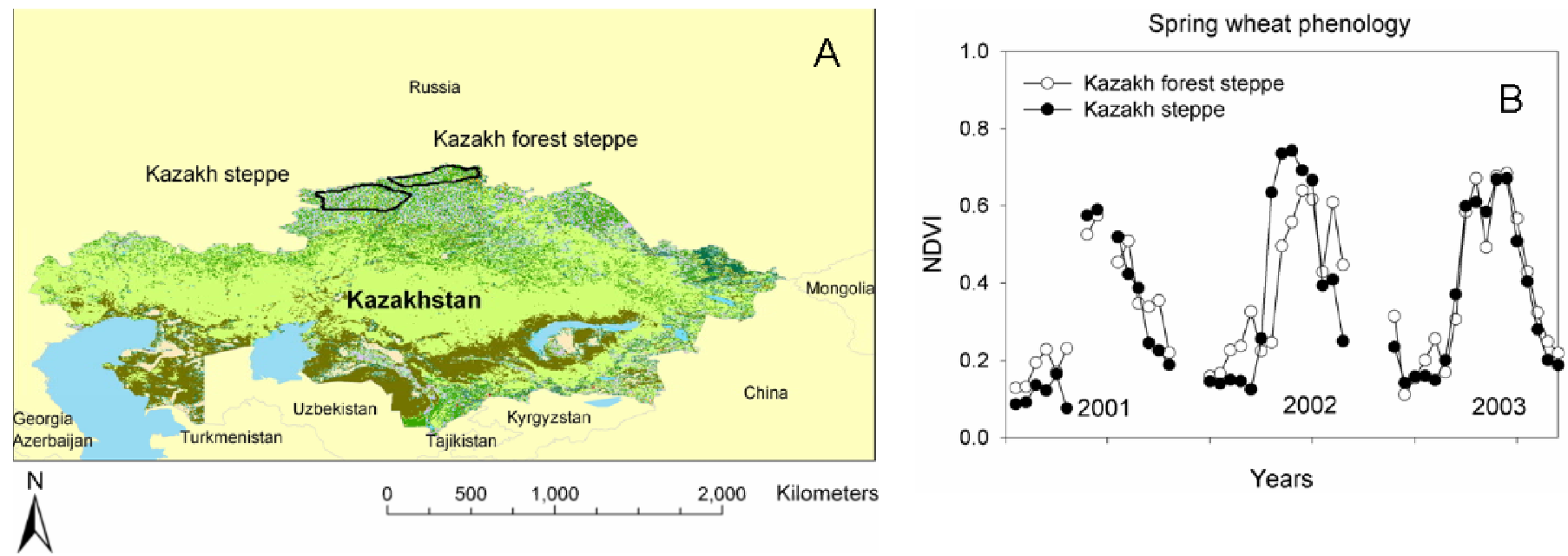

Figure 1. (A) The spring wheat study regions in Northern Kazakhstan are indicated by a black line. (B) Spring wheat phenology from two MODIS NDVI pixels observed in the Kazakh Forest Steppe and the Kazakh Steppe.

\section{B. Study regions: Kazakh forest steppe and Kazakh steppe}

Kazakhstan is the ninth largest country in the world, 2.1 million $\mathrm{km}^{2}$, and its territory covers a wide range of ecoclimatological zones. Southern Kazakhstan mainly consists of desert ecoregions [8], with irrigated agriculture restricted to the riparian zones of the Syr Darya. In eastern Kazakhstan, towards the higher altitudes of the Altai Mountains, more forested regions occur; whereas, Northern Kazakhstan mainly consists of steppes. We focused our analyses within two steppe ecoregions identified by the WWF [8]. The Kazakh forest steppe study region spans 21 $184 \mathrm{~km}^{2}$ in the northern peak of Kazakhstan. At the northwestern shoulder of the country is the Kazakh steppe study region occupying $36800 \mathrm{~km}^{2}$ (Fig. 1A).

\section{Identifying spring wheat regions}

Spring wheat in Kazakhstan generally gets planted in the end of May. The crop grows relatively quickly and is ready for harvesting mid-August. As a result of the controlled planting and harvesting, spring wheat regions have a distinctive phenological signal (Fig. 1B). Most of the regions are subject to crop rotation from which there are four main methods: fallow-wheat-wheat, fallow-wheat-wheat-barley, fallow-wheat-wheat-barley-wheat and fallow-wheat-wheatwheat [9]. Each rotation scheme has a fallow period at least every five years; thus, we can expect to find fallow years in at least part of the cropland pixels during the three available MODIS years.

To identify spring wheat areas within the study regions, we first summed all the data for each dekad. Using the following two rules, we labeled pixels as having a high probability of being planted to spring wheat:

Rule A: summed NDVI in the first dekad of June, recorded in all three years is low $(0.15<N D V I<0.9)$.
Rule B: summed NDVI in the last dekad of July, recorded in two years [no 2001 data] is high (> 1.35).

\section{Land surface phenology change}

To show how the land surface phenology model could have changed as a result of a change in cover type distribution, we determined another common cover type in the region. For each region we calculated different average land surface phenologies based on two main phenological patterns found in the area. We started with a proportion of $90 \%$ of the spring wheat pattern plus $10 \%$ of another phenology type. We compared the "baseline" phenology with nine different composite phenologies, each with a successive $10 \%$ decrease in the proportion of spring wheat.

\section{RESULTS}

\section{A. Study regions}

Fig.1B shows a realization of the spring wheat phenology pattern from each study region. They are very similar and it shows that the spring wheat in the more southerly region is not planted earlier than that of the northern region.

Based on the simple rule classification, we determined that, between 2001 and 2003, 13\% of the Kazakh forest steppe and $21 \%$ of the Kazakh steppe was planted to spring wheat. The land cover map in Fig.1A was derived from 1992-1993 data. In the Kazakh forest steppe, it shows 37\% in dryland cropland with pasture and $51 \%$ in cropland/woodland mosaics and in the Kazakh steppe it shows $48 \%$ in dryland cropland and $27 \%$ in cropland/woodland mosaic. Thus, there appears to be a decrease in spring wheat production between 1992-1993 and 2001-2003. However, these numbers should be interpreted with caution, since the land cover map is based on $1 \mathrm{~km}$ AVHRR data. 

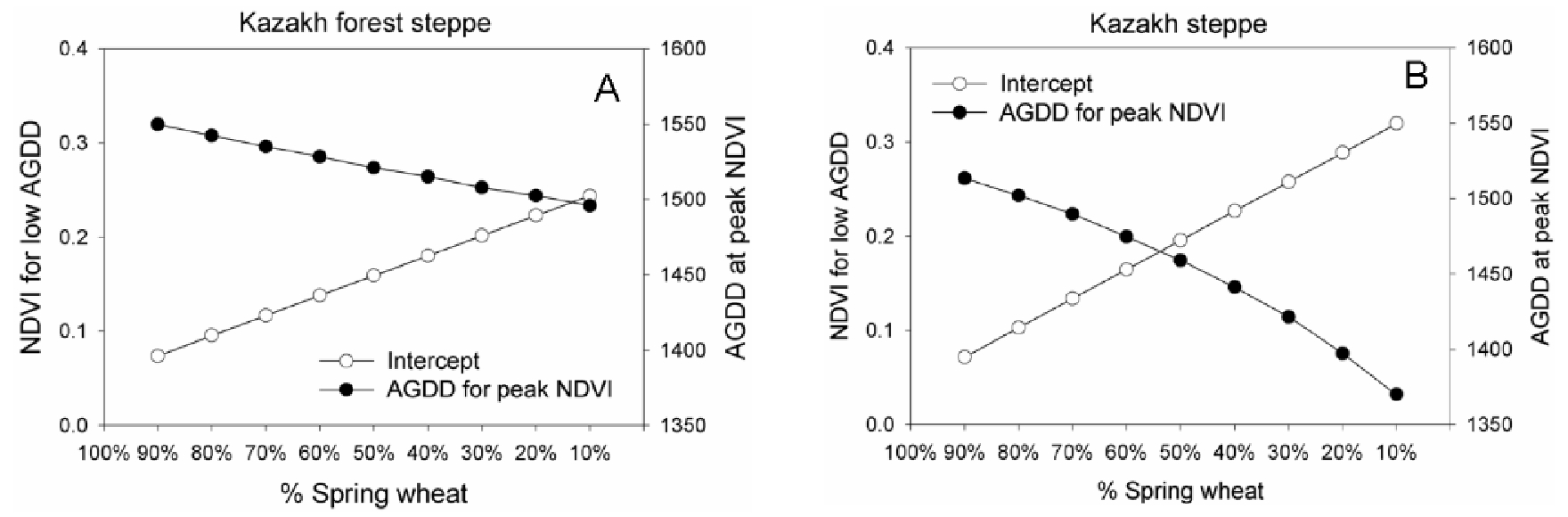

Figure 2. (A): the intercept increases from about 0.07 to about 0.24 , while the amount of AGDD necessary to reach the peak NDVI decreases from about 1550 to about 1495 (55 GDD). (B): the intercept increase from about 0.07 to about 0.33, while the amount of AGDD necessary to reach the top NDVI decrease from about 1513 to about 1370 (140 GDD).

\section{B. Land surface phenology modeling}

We calculated a weighted average from the spring wheat land surface phenology and the other main type land surface phenology. We started with a 0.9 weight for the spring wheat land surface phenology. For each average we determined the linear regression model to describe the phenology. We have used quadratic models for the phenology of these regions [6]:

$$
\mathrm{NDVI}=\alpha+\beta A G D D+\gamma A G D D^{2}
$$

The intercept, $\alpha$, gives the NDVI for low AGDD. The remaining parameters, $\beta$ and $\gamma$, are the linear and quadratic terms. The amount of AGDD for which NDVI reaches its peak value is calculated by $-\beta / 2 \gamma$.

Fig. 2A shows the NDVI for low AGDD (intercept) and the amount of AGDD that was necessary to reach peak NDVI for the different mixtures of spring wheat land cover and woodlands in the Kazakh forest steppe. Decreasing proportion of spring wheat area shows increasing intercepts and the NDVI peaks are reached for lower AGDD. This corresponds with results that we found previously when we compared the land surface phenology curves from the PAL data from a period before and after institutional change. In that case we found a 70 GDD earlier peak after institutional change and a $48 \%$ increase in intercept [6].

A similar pattern can be found for the Kazakh steppe. Here as well we find an increase in intercept for lower percentages of spring wheat cultivation. Furthermore, we find a significantly earlier peak NDVI (Fig. 2B).

\section{CONCLUSIONS}

In this brief paper we have estimated the amount of spring wheat area within two study regions. We concluded that this amount decreased significantly compared to the land cover data from 1992-1993. Despite an increase of a thousand-fold in areal resolution $(8 \mathrm{~km} \rightarrow 250 \mathrm{~m})$, this result agrees with our previous findings [6].

Furthermore, we compared land surface phenologies with differing compositions of land cover types. For decreasing proportion of spring wheat area, we find increasing intercepts in the phenology models. We also find earlier peaks. These results lend credence to the parsimonious hypothesis that significant changes in land surface phenology in these regions are primarily caused by changes in land cover/land use rather than by climatic factors.

\section{ACKNOWLEDGMENTS}

Research supported through the NASA LCLUC program. NCEP Reanalysis data were provided by the NOAA-CIRES Climate Diagnostics Center, Boulder, CO from their website at http://www.cdc.noaa.gov/. The land cover data were distributed by the Land Processes Distributed Active Archive Center (LP DAAC), located at the U.S. Geological Survey's EROS Data Center http://LPDAAC.usgs.gov.

\section{REFERENCES}

[1] Myneni, R. B., Keeling, C. D., Tucker, C. J., Asrar, G., and Nemani, R. R., "Increased plant growth in the northern high latitudes from 1981 to 1991," Nature, vol. 386, pp. 698-702, 1997.

[2] Shabanov, N. V., Zhou, L., Knyazikhin, Y., Myneni, R. B., and Tucker, C. J., "Analysis of interannual changes in northern vegetation activity observed in AVHRR data from 1981 to 1994," IEEE Trans. on Geosci. and Remote Sensing, vol. 40, pp. 115-130, 2002.

[3] Tucker, C. J., et al., "Higher northern latitude normalized difference vegetation index and growing season trends from 1982 to 1999," Int. J. of Biometeorol., vol. 45, pp. 184-190, 2001.

[4] Zhou, L., et al., "Variation in northern vegetation activity inferred from satellite data of vegetation index during 1981 to 1999," Journal of Geophysical Research, vol. 106, pp. 69-83, 2001.

[5] Alaolmolki, N. Life after the Soviet Union, The Newly Independent Republics of the Transcaucasus and Central Asia, Albany, NY: State University of New York Press, 2001.

[6] de Beurs, K. M., and Henebry, G. M., "Land surface phenology, climatic variation, and institutional change: analyzing agricultural land cover change in Kazakhstan," Remote Sens. of Environ., vol. 89, pp. 497-509, 2004.

[7] Eurasian Land Cover Characteristics Database. (Access date: June 2004).[online] http://edcdaac.usgs.gov/glcc/eadoc2 _ 0.asp

[8] Olson, D. M., et al., "Terrestrial Ecoregions of the World: A new map of life on earth," BioScience, vol. 51, pp. 933-938, 2001.

[9] FAO Plant Production and Protection Divisision (Access date: June 2004) [online] http://www.fao.org/ag/AGP 